\title{
Mineral status in blood serum of newborn calves in Assiut Governorate
}

\author{
M. A. Mohammad \\ Biochemistry unit, Animal Health Research Institute, Assiut Lab., Assuit, Egypt.
}

\begin{abstract}
The dynamics of some serum mineral concentrations during the first weeks of life of native and crossbred newborn calves in Assiut governorate were investigated. Blood samples of 25 Balady and 25 crossbred (Friesian $x$ native) male calves were investigated. Blood was drawn from calves at 1, 7, 14 and 21 days after parturition. Serum levels of calcium (Ca), phosphorous (P), magnesium $(\mathrm{Mg})$, sodium $(\mathrm{Na})$, chloride $(\mathrm{Cl})$, potassium $(\mathrm{K})$, iron $(\mathrm{Fe})$, Copper $(\mathrm{Cu})$ and zinc $(\mathrm{Zn})$ were monitored. Levels of $\mathrm{Ca}, \mathrm{P}, \mathrm{Fe}, \mathrm{Cu}$ and $\mathrm{Zn}$ increased $(\mathrm{P}<$ $0.05)$ in relation to age of Balady and crossbred calves when compared by the day 1 of age. In contrast, decreased in concentrations of $\mathrm{Na}$ and $\mathrm{Cl}(\mathrm{P}<0.05)$ in relation to age of Balady and crossbred calves when compared by the day 1 of age were detected whereas $\mathrm{Mg}$ and $\mathrm{K}$ values remained unchanged. Native calves had higher $(\mathrm{P}<0.05) \mathrm{Ca}, \mathrm{P}$ and $\mathrm{Fe}$ in the $7^{\text {th }}$ day than crossbred calves whereas $\mathrm{Na}$ and $\mathrm{Cl}$ were higher $(\mathrm{P}<0.05)$ in native calves than crossbred calves at the first day after birth. Results from this study suggested that breed and age may play an important role in mineral homeostasis during the first weeks of life in the newly borne bovine calves.
\end{abstract}

The transition at birth of a calf from a fetal to neonatal environment is very dramatic $(\mathrm{Xu}$, 1996). This transition is from sole dependency on maternal sources to one in which the neonate must maintain homeostasis (Egli and Blum, 1998). Because the physiological changes are tremendous, the first period of life is crucial for survivability (Radostits et al., 2000 and Latimer et al., 2003).

Ingestion of colostrum is important for morphological and functional development of newborns (Xu, 1996). Intake of the first colostrum causes typical metabolic and endocrine changes in blood of newly borne calves (Blum and Hammon, 2000). Colostrum intake modifies gastrointestinal tract (GIT) development and digestive and absorptive capacities in neonates, not only through provision of nutrients, minerals, vitamins and energy, but probably also due to effects of growth-promoting factors in various species, including calves (Blum and Hammon, 2000).

In newborn calves, great morphological and functional changes are necessary and calves must adapt to various environmental adaptation (Latimer et al., 2003). At birth, many changes occur, enabling survival of newborns (Heidarpour et al., 2008 and Mohri et al., 2008). Nutrient supply is converted from maternal sources to the GIT so that the GIT is the most markedly affected organ (Xu, 1996). Also, the kidney assumes control of electrolyte and water balance rather than the placenta (Radostits et al., 2000). Other changes in newborn calves are alterations in blood metabolites and functionality of the liver and other organs (Blum and Hammon, 2000). So that, the age of the calf has an important role for the precise interpretation of laboratory results (Thrall, 2004). In this concept, Mohri et al. (2007) found that many values vary with the age of the animal, with major changes occurring after birth. These modifications make the newborn calves are characterized by marked metabolic and endocrine changes which continue during the first weeks of life (Mohri et al., 2007). Changes in concentrations of various blood constituents may be related to maturity of organs, initiation of specific enzymatic activities, or simply physiological adaptation to the new environment (Thrall, 2004).

Blood biochemistry analyses are valuable tools for evaluating health of livestock, both in diagnosing disease and clinical monitoring of the individual (Meyer and Harvey, 2004). Diseases of the newborn and neonatal mortality are a major cause of economic loss in livestock production. Thus, knowledge on serum biochemical changes could help and promote the 
ability of clinicians to more accurate interpretation of clinical pathology data and diagnosis of neonatal diseases (Mohri et al., 2007). The ability to interpret laboratory data is based on knowledge regarding the normal physiologic mechanisms underlying each laboratory test (Mohri et al., 2008).

This study was undertaken to determine chronological changes of blood serum minerals in native and crossbred bovine neonates from birth to 3 weeks of age in Assiut governorate.

\section{Material and Methods}

Animals. In this study, 25 (Balady) and 25 crossbred (Friesian $\mathrm{x}$ native) male calves born from multiparous cows in different localities in Assiut Governorate were used. All the selected cattle reared under the same management and environmental conditions. Animals used in this study reared in small scales under unorganized farming with unsatisfactory standards of animal management. The common food available for the mother cows consisted mainly of Barseem (Trifolium alexandrinum) and wheat (ad lib) in addition to concentrate mixture (1-2 $\mathrm{kg} / \mathrm{head} / \mathrm{day}$ ). All newborn calves were left with their mothers and received their first colostrums for 3-4 days and then milk throughout the period of the experiment. All newborn calves and their mothers were subjected to careful clinical and laboratory investigations No metabolic or reproductive disorders occurred for cows around parturition. Also, there was no evidence of health disorders among calves in all groups.

Blood sampling. Blood was drawn from the jugular vein of all newborn calves in centrifuge tubes (without anticoagulant for collection of serum) at the day one after parturition (after fed colostrum) and at the day 7, 14 and 21 . The blood was allowed to coagulate and the harvested serum was stored at $-20^{\circ} \mathrm{C}$ until processing.

Biochemical analysis. Blood serum calcium, inorganic phosphorus, and magnesium levels were determined spectrophotometrically by using already manufactured colourometric test kits (Eltech Co. Egypt) according to manufacture instructions and the methods described by Henry (1968). The concentrations of serum sodium and potassium were carried out using flame photometer (Corning 400) using calibrated standards for $\mathrm{Na}$ and $\mathrm{K}$. The chloride concentrations in the serum were measured using a chloride meter (Corning chloride meter 925).

Blood serum was used for determination of iron, copper and zinc concentrations by using acetylene type computerized atomic absorption technique (GBC, $932 \mathrm{AA}$ ) according to its manufacture guides.

Statistical analysis. Changes of variables with age and breed of calves were analyzed using analysis of variance (ANOVA). The SPSS program for windows (SPSS, Chicago, IL) according to SPSS (1999). Significant levels were set at $\mathrm{P}<0.05$.

\section{Results}

Mean serum macro-elements profiles $(\mathrm{Ca}, \mathrm{P}$ and $\mathrm{Mg}$ ) for all calves are shown in table 1 and figure 1. It was noticed that the values of serum $\mathrm{Ca}$ in the 7 and 14 day were variably increased $(\mathrm{P}<0.05)$ in Balady and crossbred calves then the values tended to restore in Balady and decreased in crossbred calves at the day 21 , whereas the values of serum $\mathrm{P}$ were significantly increased $(\mathrm{P}<0.05)$ in the day 7,14 and 21 when compared by the day 1 of age. Blood serum magnesium values in the day 7, 14 and 21 did not changed when compared by the day 1 of age. Native calves had higher $(\mathrm{P}<0.05) \mathrm{Ca}$ and $\mathrm{P}$ in the $7^{\text {th }}$ day than crossbred calves.

Mean serum electrolytes $(\mathrm{Na}, \mathrm{K}$ and $\mathrm{Cl})$ are shown in table 2 and figure 2 . Serum $\mathrm{Na}$ and $\mathrm{Cl}$ concentrations declined $(\mathrm{P}<0.05)$ in the 7,14 and 21 day when compared with the $1^{\text {st }}$ day. On the other hand, serum $\mathrm{K}$ levels did not significantly changed by time in both breeds. Native calves had higher $(\mathrm{P}<0.05) \mathrm{Na}$ and $\mathrm{Cl}$ than crossbred calves at the first day after birth. The values of serum $\mathrm{Na}$ in native calves were significantly higher $(\mathrm{P}<0.05)$ than that in crossbred calves at the days 14 and 21, whereas the values of serum $\mathrm{Cl}$ did not significantly differed between both breeds in the days 7, 14 and 21.

Mean serum trace elements $(\mathrm{Fe}, \mathrm{Cu}$ and $\mathrm{Zn})$ for all calves are shown in table 3 and figure 3 . The concentrations of serum Fe increased $(\mathrm{P}<$ $0.05)$ in the 7, 14 and 21 day, but the values of serum $\mathrm{Cu}$ and $\mathrm{Zn}$ increased $(\mathrm{P}<0.05)$ in the days 14 and 21 in both breeds when compared with the $1^{\text {st }}$ day. Native calves had higher $(\mathrm{P}<$ 0.05 ) serum $\mathrm{Fe}$ level in the $1^{\text {st }}$ and $7^{\text {th }}$ day than crossbred calves, but the values of $\mathrm{Cu}$ and $\mathrm{Zn}$ did not differed between breeds throughout the period of the experiment. 
Table (1): Serum concentrations (Mean $\pm \mathrm{SE}$ ) of $\mathrm{Ca}, \mathrm{P}$ and $\mathrm{Mg}(\mathrm{mmol} / \mathrm{l})$ in native and crossbred newborn calves during the first 21 days of life.

\begin{tabular}{|c|c|c|c|c|c|c|}
\hline \multirow[b]{2}{*}{ Day } & \multicolumn{2}{|c|}{$\mathbf{C a}$} & \multicolumn{2}{|c|}{$\mathbf{P}$} & \multicolumn{2}{|c|}{ Mg } \\
\hline & Native & Crossbred & Native & Crossbred & Native & Crossbred \\
\hline 1 & $2.66 \pm 0.13$ & $2.71 \pm 0.15$ & $2.34 \pm 0.31$ & $2.21 \pm 0.29$ & $0.89 \pm 0.09$ & $0.92 \pm 0.14$ \\
\hline 7 & $2.97 \pm 0.22$ & $2.80 \pm 0.18^{*}$ & $2.54 \pm 0.24$ & $2.33 \pm 0.18^{*}$ & $0.91 \pm 0.12$ & $0.84 \pm 0.09$ \\
\hline 14 & $2.81 \pm 0.19$ & $2.77 \pm 0.21$ & $2.64 \pm 0.23$ & $2.57 \pm 0.28$ & $0.88 \pm 0.13$ & $0.92 \pm 0.12$ \\
\hline 21 & $2.71 \pm 0.23$ & $2.61 \pm 0.24$ & $2.59 \pm 0.19$ & $2.48 \pm 0.31$ & $0.87 \pm 0.08$ & $0.93 \pm 0.13$ \\
\hline
\end{tabular}

Table (2): Serum concentrations (Mean $\pm \mathrm{SE}$ ) of $\mathrm{Na}, \mathrm{K}$ and $\mathrm{Cl}(\mathrm{mmol} / \mathrm{l})$ in native and crossbred newborn calves during the first 21 days of life.

\begin{tabular}{lrccccc}
\hline & \multicolumn{2}{c}{ Na } & \multicolumn{2}{c}{ K } & \multicolumn{2}{c}{ Cl } \\
\cline { 2 - 7 } Day & Native & Crossbred & Native & Crossbred & Native & Crossbred \\
\hline $\mathbf{1}$ & $154.2 \pm 5.1$ & $145.1 \pm 4.6^{*}$ & $4.6 \pm 0.42$ & $3.9 \pm 0.50$ & $108.2 \pm 4.1$ & $103.1 \pm 5.6^{*}$ \\
$\mathbf{7}$ & $148.3 \pm 5.9$ & $142.6 \pm 4.1^{*}$ & $4.9 \pm 0.51$ & $4.2 \pm 0.43$ & $98.51 \pm 5.2$ & $96.11 \pm 4.3$ \\
$\mathbf{1 4}$ & $141.5 \pm 4.6$ & $128.7 \pm 4.4^{*}$ & $4.6 \pm 0.39$ & $4.5 \pm 0.41$ & $96.83 \pm 3.6$ & $96.64 \pm 4.8$ \\
$\mathbf{2 1}$ & $141.8 \pm 4.2$ & $124.3 \pm 5.1^{*}$ & $4.5 \pm 0.41$ & $4.3 \pm 0.39$ & $95.60 \pm 4.3$ & $97.21 \pm 3.9$ \\
\hline
\end{tabular}

"Significant difference between native and crossbred calves $(P<0.05)$.

Table (3): Serum concentrations (Mean $\pm \mathrm{SE}$ ) of $\mathrm{Fe}, \mathrm{Cu}$ and $\mathrm{Zn}(\mu \mathrm{mol} / \mathrm{l})$ in native and crossbred newborn calves during the first 21 days of life.

\begin{tabular}{lcccccc}
\hline & \multicolumn{2}{c}{ Fe } & \multicolumn{2}{c}{ Cu } & \multicolumn{2}{c}{ Zn } \\
\cline { 2 - 7 } Day & Native & Crossbred & Native & Crossbred & Native & Crossbred \\
\hline $\mathbf{1}$ & $15.8 \pm 0.68$ & $11.5 \pm 0.86^{*}$ & $10.2 \pm 0.51$ & $11.1 \pm 0.54$ & $8.70 \pm 0.31$ & $9.11 \pm 0.28$ \\
$\mathbf{7}$ & $22.3 \pm 0.81$ & $17.4 \pm 0.94^{*}$ & $11.1 \pm 0.43$ & $10.8 \pm 0.61$ & $10.2 \pm 0.24$ & $11.4 \pm 0.31$ \\
$\mathbf{1 4}$ & $20.6 \pm 0.74$ & $21.4 \pm 0.82$ & $13.4 \pm 0.32$ & $14.6 \pm 0.45$ & $13.1 \pm 0.26$ & $14.2 \pm 0.34$ \\
$\mathbf{2 1}$ & $21.1 \pm 0.66$ & $23.1 \pm 0.68$ & $13.5 \pm 0.41$ & $15.1 \pm 0.41$ & $13.9 \pm 0.32$ & $14.1 \pm 0.41$ \\
\hline
\end{tabular}

Significant difference between native and crossbred calves $(P<0.05)$

Fig. (1): Serum concentrations (Mean $\pm \mathrm{SE}$ ) of $\mathrm{Ca}, \mathrm{P}$ and $\mathrm{Mg}$ in native and crossbred newborn calves during the first 21 days of life.

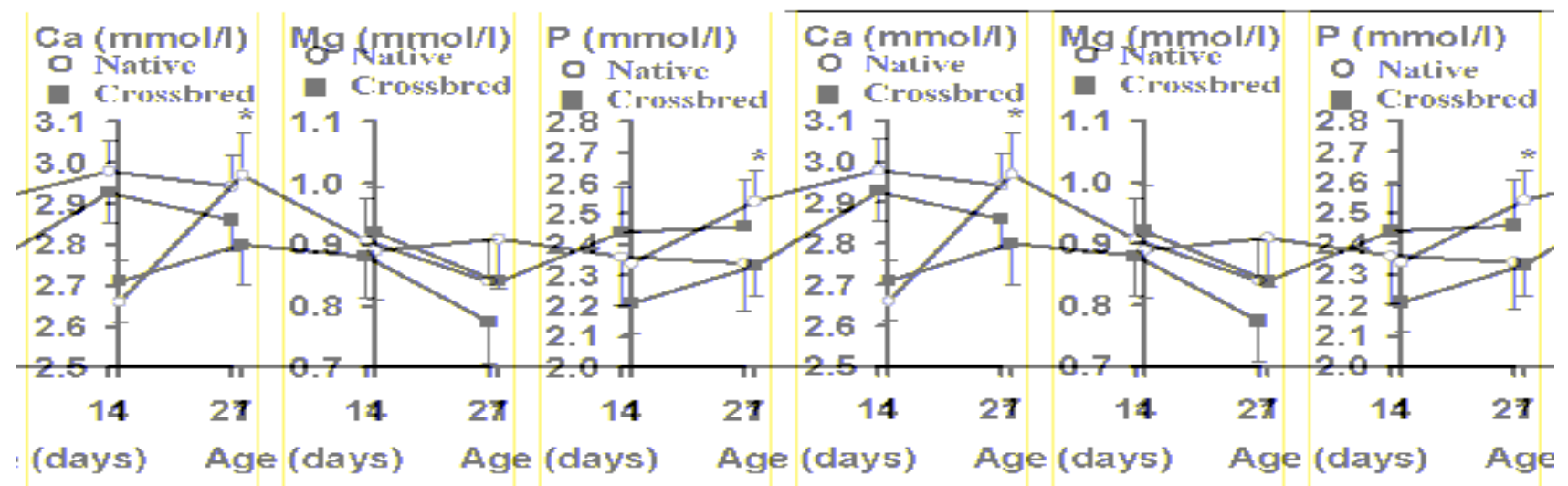

*Significant difference between native and crossbred calves $(P<0.05)$. 
Fig. (2): Serum concentrations (Mean $\pm \mathrm{SE}$ ) of $\mathrm{Na}, \mathrm{K}$ and $\mathrm{Cl}$ in native and crossbred newborn calves during the first 21 days of life.

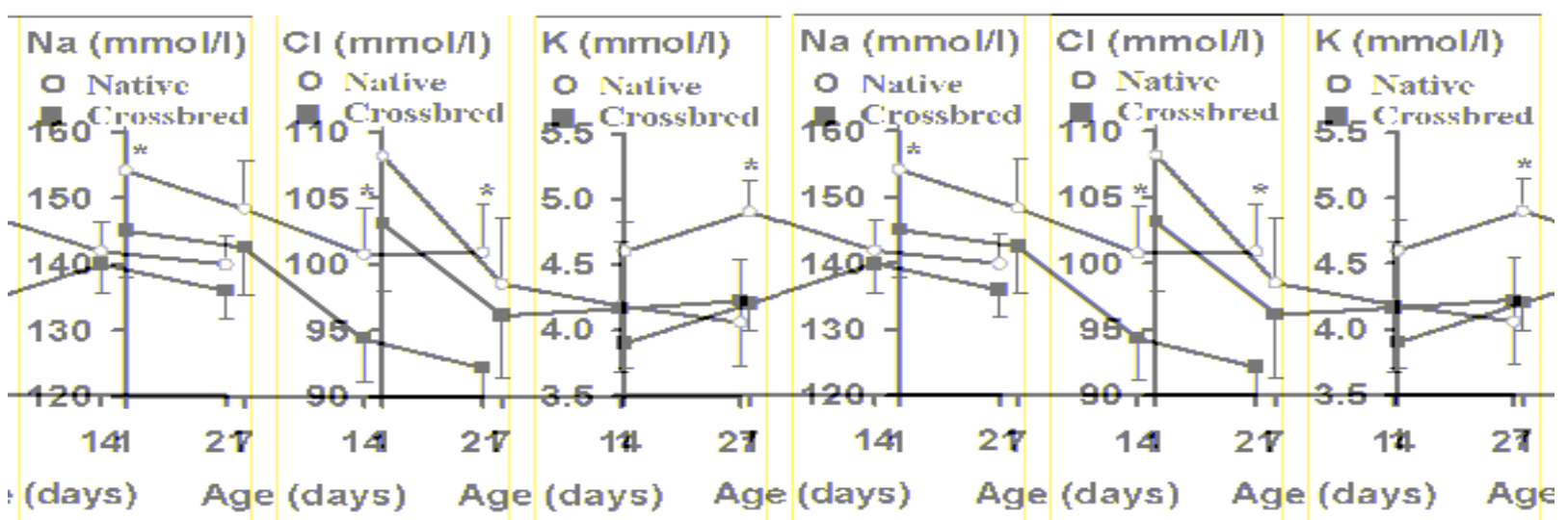

*Significant difference between native and crossbred calves $(P<0.05)$.

Fig. (3): Serum concentrations (Mean $\pm \mathrm{SE}$ ) of $\mathrm{Fe}, \mathrm{Cu}$ and $\mathrm{Zn}$ in native and crossbred newborn calves during the first 21 days of life.

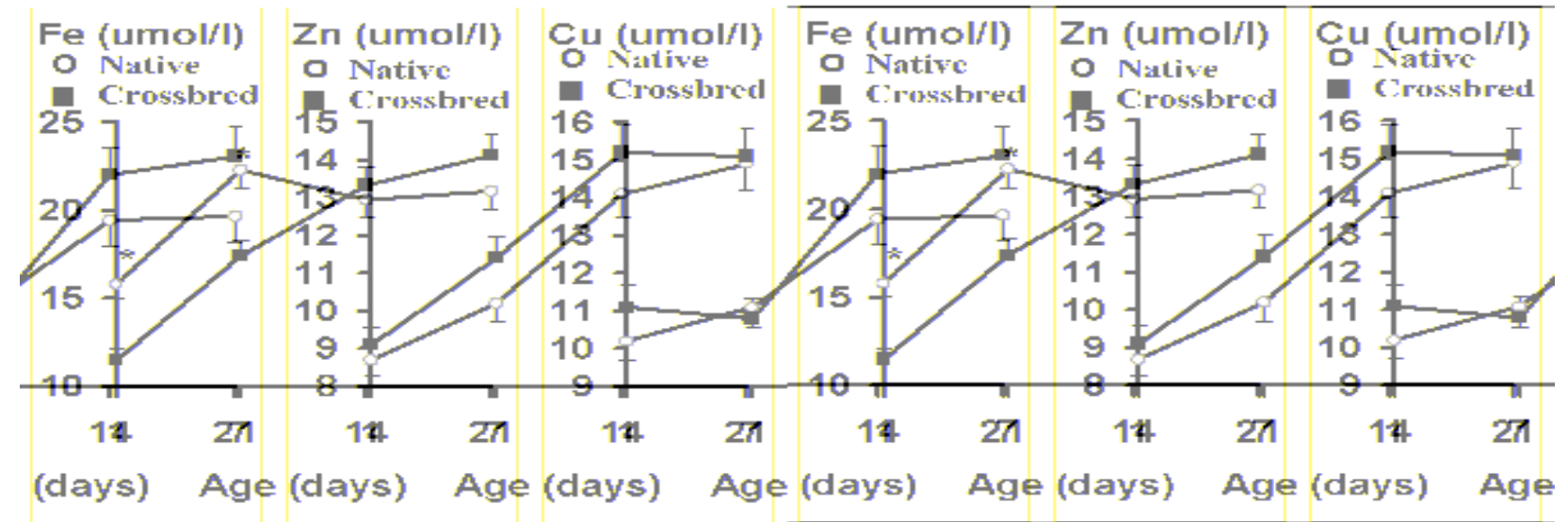

*Significant difference between native and crossbred calves $(P<0.05)$.

\section{Discussion}

In this study, serum $\mathrm{Ca}, \mathrm{P}, \mathrm{Mg}, \mathrm{Na}, \mathrm{K}, \mathrm{Cl}, \mathrm{Cu}$ and $\mathrm{Zn}$ levels were within the published values for newborn calves reared under the Egyptian environment (Mohammed, 1984; Komy et al., 1991 and Hafez et al., 2001) and also newborn calves reared in temperate areas (Radostits et al., 2000). However, the values of serum Fe were lower than those previously reported (Mohammed, 1984). The difference may be related to the variations in the feeding, management and environmental conditions (Thrall, 2004).

During the first weeks of life considerable metabolic changes occur (Blum and Hammon, 2000). In the current work, serum $\mathrm{Ca}$ and $\mathrm{P}$ levels increased in the $2^{\text {nd }}$ week of age. Agerelated changes have been previously detected for $\mathrm{Ca}$ and $\mathrm{P}$ in Friesian newborn calves (Mohri et al., 2007). Egli and Blum (1998) and Birgele and Ilgaža (2003) reported that $\mathrm{Ca}$ levels were high in the first days of life, but the same is not true for $\mathrm{P}$ and $\mathrm{Mg}$. Steinhardt and Thielscher (1999) found that $P$ concentrations changed differently in newborn calves with age. Numerous physiologic processes, particularly maximum bone mineralization in growing neonates, are associated with increased requirements of $\mathrm{Ca}$ and $\mathrm{P}$ (Radostits et al., 2000). The higher amount of $\mathrm{Ca}$ and $\mathrm{P}$ in calves may be caused by growth hormone, which is high in growing animals and enhances renal phosphate reabsorption (Rosol and Capen, 1997). Furthermore, $\mathrm{Ca}$ and $\mathrm{P}$ are the major mineral components of the mother' milk, which would affect blood concentrations of these 
minerals in the neonate (Thrall, 2004).

In the present study, serum $\mathrm{Na}$ and $\mathrm{Cl}$ concentrations were high at birth and then declined. Also, native calves had higher $\mathrm{Na}$ and $\mathrm{Cl}$ than crossbred calves at the first day after birth. These changes may be due to the high content of these minerals in the colostrum (Mohri et al., 2007). Maach et al. (1991) found reduction in $\mathrm{Na}$ and $\mathrm{Cl}$ and non-significant change in $\mathrm{K}$ in newborn Friesian calves in Moracco. Mohri et al. (2007) found that Na, K and $\mathrm{Cl}$ showed significant differences between day 14 compared with the concentration at the dayl. Changes of these variables in newborn calves with age means that there were directed time specific adaptation processes (Steinhardt and Thielscher, 1999 and Muri et al., 2005).

The concentrations of $\mathrm{Fe}, \mathrm{Cu}$ and $\mathrm{Zn}$ in the present study were low at the first day after birth and then increased. Furthermore, native calves had higher serum $\mathrm{Fe}$ level in the $7^{\text {th }}$ day than crossbred calves. These results agree with the reports of Knowles et al. (2000) and Egli and Blum (1998) who reported low iron levels in newborn calves, which may be related to the low Fe content in the diet. Kume and Tanabe (1993) reported that the increase in plasma $\mathrm{Cu}$ of newborn calves was due to the deposits of liver $\mathrm{Cu}$ rather than to colostral $\mathrm{Cu}$, but low colostral Fe was insufficient to maintain serum Fe levels. McDowell (2003) cited that newborn calves usually had low Fe stores because the maternal milk is low in $\mathrm{Fe}$.

Results from this study suggested that extreme caution must be exercised when interpreting mineral components from newborn calves of different breeds. Breed and age with the possibility of maturation of organs, play an important role in attaining mineral homeostasis during the first weeks of life in the bovines.

\section{References}

Birgele, E. and Ilgaža, A. (2003): Age and feed effect on the dynamics of animal blood biochemical values in postnatal ontogenesis in calves. Veterinarija Ir Zootechnika. 22: 5-10.

Blum, J. W. and Hammon, H. (2000): Colostrum effects on the gastrointestinal tract, and on nutritional, endocrine and metabolic parameters in neonatal calves. Livestock Prod. Sci., 66: 151-159.

Egli, C. P. and Blum, J. W. (1998): Clinical, haematological, metabolic and endocrine traits during the first three months of life of suckling Simentaler calves held in a cow-calf operation. J. Vet. Med. A, 45: 99-118.

Hafez, A.K.A; Rashad, H.M. and Kandeil, M.A. (2001): Some biochemical alterations in blood of calves and their dams in relation to different periods of age. . Proceedings of the $6^{\text {th }}$ scientific congress. Egyptian society for cattle diseases, 4-6 Nov. 2001. Assiut Univ., Egypt.
Heidarpour, B. M; Mohri, M; Seifi, H. A. and Alavi Tabatabaee A. A. (2008): Effects of parenteral supply of iron and copper on hematology, weight gain, and health in neonatal dairy calves. Vet. Res. Commun., 32: 553-61.

Henry, R. J. (1968): Clinical Chemistry, Principles and Techniques. $1^{\text {st }}$ ed. Harper and Row, New York.

Knowles, T.G., Edwards, J.E., Bazeley, K.J., Brown, S.N., Butterworth, A. and Warriss, P.D. (2000): Changes in the blood biochemical and haematological profile of neonatal calves with age. Vet. Rec., 147: 593-598.

Komy, R. Saadia; Amer, A.A and Abdel-All, Th. S. (1991): Clinical and some biochemical parameters in suckling calves. Proceedings of the First Scientific Congress. Egypt. Soc. Cattle Dis., 1-3 Dec. 1991. Assiut Univ., Egypt.

Kume, S., and Tanabe, S. (1993): Effect of parity on colostral mineral concentrations of Holstein cows and value of colostrums as a mineral source for newborn calves. J. Dairy Sci. 76:1654-1659.

Latimer, K. S.; Mahaffey, E. D. and Prasse, K.W. (2003): Duncan's and Prasse's Veterinary Laboratory Medicine: Clinical Pathology, fourth ed. Blackwell Publishing, Iowa.

Maach, L; Grunder, H. D. and Faio, A. (1991): Hemocytological and hemobiochemical investigations on clinical healthy calves (Friesian breed) in Moracco. Dtsch. Tierarztl. Wschr. 98: 94-102.

McDowell, L.R. (2003): Minerals in Animal and Human Nutrition, $2^{\text {nd }}$ ed. Elsevier Science, Amsterdam.

Meyer, D. J. and Harvey, J. W. (2004): Veterinary Laboratory Medicine: Interpretation and Diagnosis, Third ed. Saunders, St. Louis, p. 5.

Mohammed, M. I. (1984): A study on some minerals in buffaloes and cattle in health and disease. Ph. D. Thesis. Fac. Vet. Med. Alexandria Univ.

Mohri, M.; Seifi, H. A. and Maleki, M. (2008): Effects of short-term supplementation of clinoptilolite in colostrum and milk on the concentration of some serum minerals in neonatal dairy calves. Biol Trace Elem Res., 123: 116-123.

Mohri, M.; Sharifi, K. and Eidi, S. (2007): Hematology and serum biochemistry of Holstein dairy calves: Age related changes and comparison with blood composition in adults. Res. Vet. Sci., 83: 30-39.

Muri, C.; Schottstedt, T.; Hammon, H. M.; Meyer, E. and Blum, J. W. (2005): Hematological, metabolic, and endocrine effects of feeding vitamin A and lactoferrin in neonatal calves. J. Dairy Sci., 88: 1062-1077.

Radostits, O.M., Gay, C.C., Blood, D.C., Hinchcliff, K.W., (2000): Copper. In: Veterinary Medicine, 9th ed. London, pp. 1487-1502.

Rosol, T.J. and Capen, C.C. (1997): Calcium regulating hormones and diseases of abnormal mineral (calcium, phosphorus, magnesium) metabolism. In: Kaneko, J.J., Harvey, J.W., Bruss, M.L. (Eds.), Clinical Biochemistry of Domestic Animals, fifth ed. Academic Press, San Diego, pp. 619-702.

SPSS (1999): ANOVA in Sample Power Statistics, SPSS, 10.0.1 Syntax Reference Guide for SPSS Base. SPSS Inc., 233 South Wacker Drive, Chicago, IL. pp. 111-119.

Steinhardt, M. and Thielscher, H.H. (1999): Quality of development and adaptation reactions of dairy calves at specific age periods in early life. Effect of rearing variations on proteins and minerals and on metabolic variables of blood. Dtsch Tierarztl Wochenschr. 106: 510-518.

Thrall, M.A. (2004): Veterinary Hematology and Clinical Chemistry. $1^{\text {st }}$ ed. Lippincott Williams and Wilkins, Baltimore, pp. 45-46. 


\section{صورة المعادن في مصل دم العجول حديثة الولادة في محافظة أسيوط}

في هذه الدراسة تم فحص تغيرات المعادن خلال الأسابيع الأولى في مصل دم عينة من العجول البلدي والخليط حديثة الولادة في محافظة أسيوط. ولهذا الغرض تم فحص عدد 25 عجل بلاي و 25 عجل خليط (فريزيان × محلي). تم الحصول على عينـات دم من هذه العجول في اليوم الأول بعد الولادة ثم في اليوم 7 و 14 و 21 وذلك لقياس مستوى الكالسيوم والفوسفور و الماغنيسيوم والصوديوم والبوتاسيوم

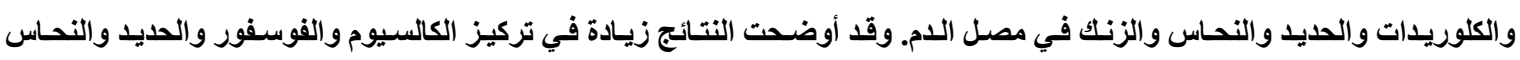
و الزتك (P>05) بمرور الوقت في كل من العجول البلاي والخليط مقارنة باليوم الأول من العمر وفي المقابل كان هنـاك نقص في تركيز الصوديوم والكلوريدات (P>0.05) بمرور الوقت في كل من العجول البلدي والخليط مقارنـة بـاليوم الأول من العمر بينمـا لم تتغير قيم

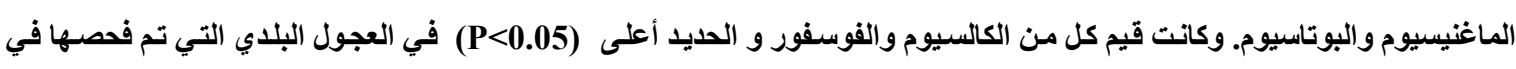

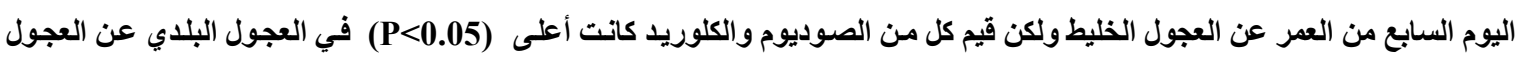
الظليط في اليوم الأول من العمر. نتائج هذه الاراسة ترجح أن العمر والسـلالة لهما دورا هامسا في اتزان بعض عناصر اللام أثناء الأسـابيع 